Sympozjum

Rok XXIII 2019, nr 2(37), s. 93-115

\author{
ks. Eugeniusz Ziemann SCJ \\ Wyższe Seminarium Misyjne Księży Sercanów w Stadnikach \\ ORCID: 0000-0002-4623-0026; e-mail: eugenio@kr.onet.pl \\ https://doi.org/10.4467/25443283SYM.19.025.11427
}

\title{
MISYJNY WYMIAR CHARYZMATU \\ SERCAŃSKIEGO
}

\section{A DIMENSION OF DEHONIAN MISSION CHARISM}

\begin{abstract}
Abstrakt
Refleksja nad misyjnym wymiarem charyzmatu sercańskiego wpisuje się w bogaty kontekst historii oraz duchowości życia zakonnego. Na przełomie XIX i XX wieku powstała we Francji większość instytutów zakonnych męskich i żeńskich w odpowiedzi na religijne i społeczne potrzeby ówczesnej Europy. Zakładane nowe zgromadzenia zakonne ubogacały Kościół specyficznymi formami czynnego życia apostolskiego, bazując na charyzmacie i misji swoich założycieli, a także bogatej duchowości zakonów mniszych, żebrzących i kleryckich. Osobiste pragnienie połączenia kapłaństwa z życiem zakonnym stało się dla ojca Leona Dehona inspiracją do założenia Zgromadzenia Księży Najświętszego Serca Jezusowego dla dobra Kościoła oraz osobistego uświęcenia jego członków.

Słowa kluczowe: apostolat, charyzmat, instytut zakonny, misja, stowarzyszenie życia apostolskiego, zakon, zgromadzenie, życie zakonne
\end{abstract}




\begin{abstract}
The reflection upon the Dehonian mission charism fits into the rich context of the history of religious life. At the turn of the $19^{\text {th }}$ and $20^{\text {th }}$ century most of the religious orders for men and women in France came into being, as the response to the social needs of Europe of that time. Shaping of the new religious orders enriched the Church with the specific forms of apostolic life, based on charisms and missions of their founders, and the rich spirituality of the orders of monks, beggars and clerics. Personal desire to combine both priesthood and religious life became the inspiration for Fr. Leon John Dehon to found the Congregation of the Priests of the Sacred Heart for the benefit of the Church and for the personal sanctification of its members.
\end{abstract}

Keywords: apostolate, charism, religious Congregation, mission, association of apostolic life, order Congregation, religious

\title{
Wstęp
}

We wstępie do adhortacji Vita consecrata papież Jan Paweł II stwierdza: „Wszyscy zdajemy sobie sprawę, jakim bogactwem jest dla wspólnoty kościelnej dar życia konsekrowanego w całej różnorodności jego charyzmatów i instytucji”' ${ }^{1}$. To przekonanie papieża o znaczeniu i roli instytutów życia konsekrowanego oraz instytutów życia apostolskiego dla Kościoła odnosi się zwłaszcza do specyfiki charyzmatu realizowanego w określonym apostolacie i misji.

Charyzmat (gr. charisma - dar, łaska) jako specyficzny dar łaski pochodzi bezpośrednio od Ducha Świętego. Udzielony konkretnej osobie lub osobom wspólnoty chrześcijańskiej, służy dobru całego Kościoła. Akcent położony na dobro Kościoła wyróżnia charyzmat od innych otrzymanych łask, które nie muszą posiadać przeznaczenia społecznego. Według św. Pawła, teologa charyzmatów, są one udzielane wszystkim

\footnotetext{
${ }^{1}$ Jan Pawee II, Posynodalna adhortacja apostolska Vita consecrata, Rzym 1996, 2.
} 
chrześcijanom. Każdy wierzący otrzymał swój osobisty charyzmat dla ubogacenia nim wspólnoty Kościoła (por. 1 Kor 7,7). Charyzmaty, które otrzymują poszczególni ludzie i wspólnoty, nie mają jednak na celu ich osobistego uświęcenia, lecz uświęcenie innych w zbawczej misji Kościoła. Kryterium oceniającym ich autentyczność jest wiara w Jezusa Chrystusa (por. 1 Kor 12,3; 2 Kor 4,13) oraz miłość braterska służąca dobru wspólnoty (por. Rz 12,9; Kol 1,8; Ga 5,22; Ef 4,3)2.

Zagadnienie charyzmatów w Kościele podjął papież Pius XII w encyklice Mistici Corporis Christi (1943), akcentując, iż stanowią one istotny element Kościoła jako wspólnoty. Z kolei ojcowie II Soboru Watykańskiego użyli tego terminu 14 razy, m.in. w Konstytucji dogmatycznej o Kościele Lumen gentium, podkreślając, iż Duch Święty zesłany na Kościół mieszka w Kościele i jednoczy go „(...) we wspólnocie i posłudze, obdarza go rozmaitymi darami hierarchicznymi oraz charyzmatycznymi i za ich pomocą kieruje nim oraz przyozdabia swoimi owocami (por. Ef 4,11-12; 1 Kor 12,4; Ga 5,22)”3. Określenie „charyzmat” jest także obecne w Konstytucji dogmatycznej o Objawieniu Bożym Dei Verbum ${ }^{4}$, w Dekrecie o apostolstwie świeckich Apostolicam actuositatem ${ }^{5}$, w Dekrecie o działalności misyjnej Kościoła Ad gentes divinitus ${ }^{6}$ oraz w Dekrecie o posłudze i życiu kapłanów Presbyterorum ordinis ${ }^{7}$.

Termin „charyzmat” w odniesieniu do życia zakonnego (konsekrowanego) po raz pierwszy został użyty przez Pawła VI w adhortacji Evangelica testificatio, w której papież mówi o charyzmacie założycieli

2 Por. R. Jasiak, Charyzmaty, w: M. Chmielewski (red.), Leksykon duchowości katolickiej, Lublin-Kraków 2002, s. 112-113.

3 II Sobór WATYKAŃsKi, Konstytucja dogmatyczna o Kościele Lumen gentium, Rzym $1964,4$.

${ }^{4}$ Por. Tenże, Konstytucja dogmatyczna o Objawieniu Bożym Dei Verbum, Rzym $1965,8$.

${ }^{5}$ Por. TEnżE, Dekret o apostolacie świeckich Apostolicam actuositatem, Rzym 1965, 3. 30 .

${ }^{6}$ Por. Tenże, Dekret o działalności misyjnej Kościoła Ad gentes divinitus, Rzym 1965, 4. 23. 28.

7 Por. TENżE, Dekret o posłudze i życiu kapłanów Presbyterorum ordinis, Rzym 1965, 4. 9. 
zakonów ${ }^{8}$, życia zakonnego ${ }^{9} \mathrm{i}$ instytutów zakonnych ${ }^{10}$ jako o owocu Ducha Świętego zawsze działającego w Kościele ${ }^{11}$. W tym samym duchu wypowiedziała się też Stolica Apostolska w dokumentach: Mutuae relationes (1978), Optiones Evangelicae (1980), Dimensio contemplativa (1980), Redemptionis donum (1984), Potissimum institutioni (1990), Congregavit nos in unum (1994), a zwłaszcza Jan Paweł II w epokowej, posynodalnej adhortacji apostolskiej o życiu konsekrowanym i jego misji w Kościele i świecie Vita consecrata (1996). Należy podkreślić, że charyzmat życia konsekrowanego stanowi jedną z form życia chrześcijańskiego, która przez naśladowanie Chrystusa przemienia osobę i uzdalnia ją do życia i działania dla dobra Kościoła.

Charyzmat instytutu zakonnego lub stowarzyszenia życia apostolskiego jest nierozerwalnie związany z misją i jej profetycznym charakterem jego członków w Kościele i w świecie przez świadectwo życia, czynów i słów opierających się na wartościach rad ewangelicznych. Liczne instytuty zakonne męskie i żeńskie, czerpiąc $\mathrm{z}$ charyzmatu założycieli oraz z charyzmatu instytutu, są zaangażowane w ewangelizacyjną i apo-

${ }^{8}$ Jest to dar osobisty, który przemienia osobę założyciela w celu przygotowania go do podjęcia szczególnego powołania i misji w Kościele. Charyzmat ten posiada też wymiar wspólnotowy, gdyż dla realizacji misji angażuje więcej osób, a także kościelny - jest ofiarowany przez założyciela i wspólnotę Kościołowi. W tym kontekście trzeba też rozróżnić charyzmat osobisty założyciela, który uzdalnia go do założenia nowego dzieła bez względu na jego historyczną realizację i specyficzną duchowość, od charyzmatu założyciela, który trzeba wcielić w życie. Osobisty charyzmat jest nieprzekazywalny. Przekazywalny jest styl życia duchowego pierwszej wspólnoty. Por. J. GoGOLA, Zasady wierności charyzmatowi założyciela, Kraków 2000, s. 216-217.

${ }_{9}^{9}$ Charyzmat życia zakonnego stanowi jedną z form powołania chrześcijańskiego, które obejmuje całą osobę we wszystkich wymiarach jej egzystencji. Będąc darem o przeznaczeniu społecznym, najpierw ubogaca osobę obdarowaną. Charyzmat ten, ze względu na swoją właściwość, charakteryzuje wszystkie rodziny zakonne w ich entuzjazmie, zachwycie, porywie, nie będąc owocem wysiłków człowieka, lecz skutkiem mocy Ducha Świętego. Por. tamże, s. 218-219.

${ }^{10}$ Charyzmat instytutu uzdalnia jego członków do odczytywania i aktualizowania pierwotnej inspiracji założyciela. Ciągłość relacji z założycielem nie może być przerwana, chociaż pod wpływem nowych wyzwań historycznych i wrażliwości może być dostosowana pod natchnieniem Ducha Świętego. Por. tamże, s. 219.

${ }^{11}$ Por. Pawee VI, Adhortacja Evangelica testificatio, Rzym 1971, 11. 
stolską działalność Kościoła, zwłaszcza na misjach ad gentes, będących kontynuacją misji zbawczej Chrystusa przekazanej Apostołom (por. Mt 28,18-20; Mk 15-18; Łk 24,47-48; J 17,18-23; 20,21-23), a wynikających ze specyfiki ich charyzmatu ${ }^{12}$. Do grona tych instytutów zakonnych należą księża sercanie realizujący swój specyficzny charyzmat w misji Kościoła.

\section{Geneza i rozwój instytutów życia zakonnego na bazie ich charyzmatu i misji}

W historii Kościoła zarówno mężczyźni, jak i kobiety dążyli do doskonałości chrześcijańskiej przez podejmowanie radykalnego stylu życia bazującego na radach ewangelicznych: czystości, ubóstwie i posłuszeństwie, $\mathrm{w}$ celu swobodnego i wiernego naśladowania Chrystusa przez pustelnicze życie w samotności lub we wspólnotach zakonnych ${ }^{13}$. W czasach apostolskich wspólnotowy styl życia praktykowali Apostołowie wraz z Najświętszą Maryją Panną na czele (por. Dz 2,42-47; 4,32-37), a także pierwsi chrześcijanie, którzy gromadzili się na wspólnej modlitwie, łamaniu chleba oraz wzajemnym dzieleniu się dobrami materialnymi (por. Dz 5,1-11). W epoce ojców Kościoła, zwłaszcza w okresie prześladowań, dziewice, asceci oraz celibatariusze udawali się na pustynię, aby w samotności oddawać się modlitwie i ascezie. Taki styl życia przejęli późniejsi anachoreci, cenobici oraz eremici, dając początek mniszemu życiu zakonnemu, które rozwijało się zarówno na Wschodzie, jak i na Zachodzie.

\section{Zakony mnisze}

Od IV wieku męskie i żeńskie zakony mnisze kształtowały swoją tożsamość na bazie przyjętej reguły. Jedną z najstarszych była reguła Pachomiusza, normująca zasady życia cenobickiego opartego na dążeniu

12 Por. S. Kasprzak, Misje, w: M. Sitarz (red.), Leksykon prawa kanonicznego, Lublin 2019, k. 1751-1756; J. GAJdA, Misyjna duchowość, w: M. Chmielewski (red.), Leksykon duchowości..., dz. cyt., s. 542-545.

13 Por. II Sobór WATYKański, Dekret o przystosowanej do współczesności odnowie życia zakonnego Perfectae caritatis, Rzym 1965, 1. 
do doskonałości przez wspólne mieszkanie, pracę, modlitwę i współodpowiedzialność za siebie ${ }^{14}$. Ważne miejsce $\mathrm{w}$ rozwoju życia mniszego oraz kształtowaniu się monastycyzmu zachodniego miała Reguła Mistrza $^{15}$, pochodząca od anonimowego autora z początku VI wieku. Obszernie cytował ją Benedykt z Nursji w regule napisanej około 540 roku na Monte Casino ${ }^{16}$.

Benedyktyńską regułę przyjęły liczne zakony mnisze gromadzące anachoretów, eremitów i cenobitów, którzy od XII wieku, dzieląc się na mnichów $i$ konwersów, byli zobowiązani zgodnie z tradycjami tych zakonów zmieniać swoje obyczaje (conversio morum) m.in. przez wyrzeczenie się świata, podejmowanie walki z wadami oraz zerwanie z wszystkim, co oddziela mnicha od Boga. Przyjmowali też monastyczną hierarchię wartości, opartą na duchowości pustyni, zwłaszcza przez nabywanie cnoty posłuszeństwa, pokory i miłości, oddanie się Bogu przez modlitwę liturgią godzin, poszukiwanie Boga i poznawanie Go przez kontemplację i studium (lectio divina) oraz miłość apostolską związaną z dozwolonymi formami działalności duszpasterskiej ${ }^{17}$. Do kategorii zakonów mniszych opartych na regule Benedykta należą m.in: benedyktyni, kameduli, cystersi, kartuzi, trapiści, mechitarzyści, zaś na regule Augustyna ${ }^{18}$, stanowiącej zbiór przepisów życia zakonnego, powstali m.in.: paulini, hieronimici, a także od końca XVII wieku zakony mnisze należące do Kościołów obrządku wschodniego, zwłaszcza maronickiego.

\section{Kanonicy regularni}

Geneza zakonu kanoników regularnych wiąże się z pierwszymi diakonami i prezbiterami rezydującymi przy siedzibach biskupów. Zaangażowani w działalność duszpasterską, praktykowali chórową recyta-

14 Por. J. Marecki, Zakony w Polsce, Kraków 2000, s. 5.

15 Por. M. Daniluk, Reguła Mistrza, w: E. Gigilewicz (red.), Encyklopedia katolicka, t. 16, Lublin 2012, k. 1328-1329.

16 Por. M. Daniluk, Encyklopedia instytutów życia konsekrowanego i stowarzyszeń życia apostolskiego, Lublin 2000, s. 50-53.

17 Por. Tenże, Mnisze zakony, w: E. Ziemann (red.), Encyklopedia katolicka, t. 12, Lublin 2008, k. 1458.

18 Por. M. Daniluk, Encyklopedia instytutów..., dz. cyt., s. 41-42. 
cję godzin kanonicznych oraz życie wspólne. Promotorem tej formy życia wspólnego był Augustyn, który w Hippo Regius (Hipponie) założył pierwszy klasztor dla duchownych bez surowej ascezy mniszej, która mogłaby utrudniać prowadzenie pracy duszpasterskiej. W nurcie reformy gregoriańskiej, zapoczątkowanej na synodzie laterańskim w 1059 roku przez Hildebranda, późniejszego papieża Grzegorza VII, na podstawie reguły Augustyna, ukształtowała się nowa kategoria zakonów pod nazwą kanoników regularnych ${ }^{19}$. W odróżnieniu od mnichów prowadzili oni działalność duszpasterską, praktykowali życie wspólne oraz ubóstwo indywidualne.

Dynamiczny rozwój tego zakonu nastąpił w XII wieku. Działające w tym czasie ich kongregacje obejmowały kilkaset klasztorów głównie w Europie Północnej, basenie Morza Śródziemnego, a także w Czechach i Polsce. W okresie średniowiecza kanonicy regularni posiadali około 2500 klasztorów, m.in. słynne opactwo św. Wiktora w Paryżu i Sankt Florian w Austrii ${ }^{20}$. W okresie reformacji liczne ośrodki uległy kasacie. Odrodzenie zakonu nastąpiło po Soborze Trydenckim, owocując nowymi kongregacjami. Działania rewolucji francuskiej i wojny napoleońskie ponownie osłabiły zakon, jednak na przełomie XIX i XX wieku kanonicy regularni podjęli działalność misyjną w duchu charyzmatu niemalże na wszystkich kontynentach ${ }^{21}$. Do tej kategorii zakonów należą m.in.: Kanonicy Laterańscy Najświętszego Zbawiciela, Kanonicy Regularni Laterańscy św. Augustyna, Kanonicy Regularni św. Mikołaja i Bernarda, a także bożogrobcy, Bracia Krzyża Świętego, Bracia Szpitalni Najświętszej Maryi Panny, krzyżacy i norbertanie (premonstratensi).

\section{Zakony żebrzące}

W XIII wieku pojawiła się nowa kategoria zakonów, na własnych regułach, nazywana żebrzącymi mendykantami (łac. mendicare - żebrać). Ich charyzmatyczną misją w Kościele było ubóstwo indywidualne oraz

19 Por. tamże, s. 167-169.

20 Zob. A. L. Amat, La vita consacrata le varie forme dalle origini ad oggi, Roma 1991, s. $153-162$.

${ }^{21}$ Por. J. KŁoczowski, Wspólnoty chrześcijańskie, Kraków 1964, s. 227-228. 234-236. 
wspólnotowe. Osiedlali się zwłaszcza w miastach, gdzie zakładali konwenty, prowadzili działalność naukową na uniwersytetach, a także apostolat społeczno-religijny i charytatywny. Łącząc misję kapłaństwa sakramentalnego z życiem zakonnym, byli zaangażowani w kaznodziejstwo, misje oraz duszpasterstwo przy własnych kościołach. Na terenach misyjnych podejmowali inicjatywy apostolskie związane z życiem religijnym, charytatywnym i polityczno-społecznym Kościoła.

Zakony żebrzące w odróżnieniu od zakonów mniszych posiadały zhierarchizowany system organizacji (kustodia, prowincja zakonna) oraz władzy (przełożony lokalny, prowincjał, generał), realizowały braterski ideał życia (wszyscy są równi w prawach z wyjątkiem wykonujących posługę święceń), znoszący podział na chóry zakonne ${ }^{22}$. Owocem ich działalności apostolskiej były tzw. trzecie zakony, które skupiały osoby praktykujące ewangeliczny ideał doskonałości chrześcijańskiej oparty na duchowości zakonów regularnych, którym prawnie podlegały ${ }^{23}$.

Do najbardziej znanych zakonów żebrzących należą: augustianie eremici, augustianie rekolekci i augustianie bosi, bonifratrzy, dominikanie, franciszkanie, bracia mniejsi konwentualni, Trzeci Zakon Regularny św. Franciszka, kapucyni, karmelici, karmelici bosi, mercedariusze, minimici, serwici i trynitarze.

\section{Klerycy regularni}

Kolejną kategorię zakonów nowego typu stanowią klerycy regularni (łac. clerici regulares). W znaczeniu prawnym nazwa ta odnosiła się do wszystkich duchownych zakonnych w odróżnieniu ich od duchowieństwa świeckiego. Od XVI wieku stała się określeniem własnym zakonów kleryckich w odróżnieniu od zakonów mniszych i kanonickich, dla których przyjęcie charyzmatu życia zakonnego stanowiło fundament dla prowadzenia działalności apostolskiej w kontekście aktualnych potrzeb Kościoła. Ich misją był apostolat wzorowany na pracy duszpasterskiej

22 Zob. tamże, s. 324-372.

23 Zob. T. Wytrwaє Zakony Trzecie, w: E. Gigilewicz (red.), Encyklopedia katolicka, t. 20, Lublin 2014, k. 1196-1197; M. DAniluk, Encyklopedia..., dz. cyt., s. 370-371. 
duchowieństwa diecezjalnego, zwłaszcza przez wychowanie i kształcenie młodzieży oraz rozwijanie dzieł miłosierdzia. Członkowie zakonów kleryckich nie byli zobowiązani do chórowego odmawiania godzin kanonicznych i przyjęcia habitu, jednak praktykowali życie wspólne wzorowane na kanonikach regularnych oraz akceptowali własność wspólną dóbr materialnych ${ }^{24}$. Ta kategoria zakonów obejmowała barnabitów, jezuitów, pijarów, somasków i teatynów. Warto też podkreślić, iż prowadzona przez nich działalność apostolska przyczyniła się do dynamicznego rozwoju działalności misyjnej Kościoła w dalekich krajach określanej jako misje ad gentes - do narodów.

Powstawanie odrębnych form życia zakonnego trwało do końca XVI wieku. Wspólną cechą wszystkich powstałych zakonów były śluby uroczyste, które należały do istoty zakonu i pociągały za sobą określone skutki prawne dla części ich członków (łac. regulares) oraz członkiń (łac. monache). Członkowie późniejszych wspólnot zakonnych składali śluby zwykłe. Kodeks prawa kanonicznego z 1917 roku (kan. 488) i Kodeks prawa kanonicznego z 1983 roku (kan. $1193 \$ 2$ ), zachowując podział na uroczyste śluby zakonne i zwykłe (w zgromadzeniach), wyraził zgodę, aby zakony zachowały je wyłącznie w prawie własnym.

Do kategorii zakonów zalicza się też gałęzie żeńskie zakonów męskich, które są określane terminem „mniszki” (łac. sanctimoniales, moniales, monachae). Na ogół prowadziły one życie kontemplacyjne, zachowując klauzurę papieską. Status mniszek reguluje Instrukcja Kongregacji do spraw Życia Konsekrowanego i Stowarzyszeń Życia Apostolskiego Verbi sponsa (1999). Nazwę „mniszki” zachował Kodeks prawa kanonicznego z 1983 roku (kan. 686 \$2). Należą do nich m.in.: bazylianki, benedyktynki, cysterki, kamedułki, kartuzjanki, kanoniczki, norbertanki, dominikanki, klaryski, koncepcjonistki, anuncjatki, bernardynki, koletanki, urbanistki, kapucynki, trynitarki, hieronimitki, karmelitanki, komandorki św. Jana Jerozolimskiego, serwitki, brygidki, minimitki, mercedariuszki, a także urszulanki, wizytki, redemptorystki i pasjonistki ${ }^{25}$.

24 Zob. A. L. Amat, La vita consacrata..., dz. cyt., s. 279-297, 299-324.

25 Por. E. Ziemann, Zakon, w: E. Gigilewicz (red.), Encyklopedia katolicka, t. 20, Lublin 2014, k. 1191-1192. 
Wiek XVI, będący czasem głębokich reform w Kościele katolickim, a także destrukcyjnych działań ruchów reformacyjnych, owocował zakładaniem wspólnot osób duchownych i świeckich, które praktykowały życie wspólne bez ślubów zakonnych - stowarzyszenia życia wspólnego (od 1983 roku zwane stowarzyszeniami życia apostolskiego) lub życie wspólne oparte na ślubach zwykłych czasowych i wieczystych zgromadzenia zakonne.

\section{Stowarzyszenia życia apostolskiego}

Geneza stowarzyszeń życia apostolskiego sięga 2. połowy XVI wieku i wiąże się z działalnością apostolską w Rzymie św. Filipa Neri. Założone przez niego oratorium gromadziło wiernych świeckich i duchownych w celu wspólnego praktykowania modlitwy i pogłębiania życia religijnego. Wyodrębnieni z niego księża utworzyli w 1551 roku stowarzyszenie pod nazwą filipini, które podjęło pracę duszpasterską zwłaszcza wśród dzieci, młodzieży i osób najbardziej potrzebujących ${ }^{26}$.

Tymczasem we Francji kard. Piotr de Bérulle, wzorując się na oratorium św. Filipa Neri, założył w 1611 roku w Paryżu oratorium kapłańskie (francuskie) dla odnowy duchowieństwa diecezjalnego w duchu Soboru Trydenckiego, m.in. przez pogłębianie świętości osobistej kapłana we wspólnocie, a także podejmowanie zorganizowanej działalności duszpasterskiej ${ }^{27}$.

Te dwa modele życia wspólnego kapłanów zainspirowały Wincentego à Paulo do założenia w 1629 roku w Paryżu stowarzyszenia lazarystów. Powstające wspólnoty kapłańskie podejmowały działalność misyjną, duszpasterską i charytatywną, a także formację intelektualno-duchową w seminariach ${ }^{28}$.

26 Por. R. Boureau, Loratoire en France, Paris 1991, s. 9-18.

27 Por. tamże, s. 19-62; E. Ziemann, Oratorianie francuscy, w: E. Gigilewicz (red.), Encyklopedia katolicka, t. 14, Lublin 2010, k. 709-710; M. CHMIELEwsкi, Wielka ksiega duchowości katolickiej, Kraków 2015, s. 549-550. 551-552; E. Ziemann, Być kapłanem Serca Jezusowego, Kraków 2006, s. 124-132.

28 Por. M. Chmielewski, Wielka księga duchowości katolickiej, dz. cyt., s. 555-565. 
Do znaczących męskich stowarzyszeń życia apostolskiego realizujących swój apostolat na bazie charyzmatu misyjnego, duszpasterskiego, charytatywnego i edukacyjnego należą m.in.: sulpicjanie (1642), eudyści (1643), Towarzystwo Misji Zagranicznych z Paryża (1660), Misjonarze Najświętszej Krwi (1815), pallotyni (1835), Towarzystwo Misji Afrykańskich (1856), Towarzystwo Misyjne św. Józefa z Mill Hill (1866), Biali Ojcowie (1868), Instytut Hiszpański Misji Zagranicznych św. Franciszka Ksawerego (1899), Towarzystwo Misji Zagranicznych św. Kolumbana (1917), Papieski Instytut Misji Zagranicznych (1926), Braterstwo Kapłańskie św. Piotra $(1988)^{29}$.

Na uwagę zasługuje też liczne grono żeńskich stowarzyszeń życia apostolskiego, zaangażowanych głównie w apostolat charytatywny i edukacyjny. Do najbardziej znanych należą m.in.: szarytki (1617), Stowarzyszenie Córek św. Franciszka Salezego (1872), Pomocnice Serafickiego Dzieła Miłosierdzia (1919), Misyjne Pomocnice Społeczne (1966), Stowarzyszenie Oblatek „Mater Orphanorum” (1967), Siostry Służby Spolecznej $(1984)^{30}$.

\section{Zgromadzenia zakonne}

Nową formą życia zakonnego opartego na duchowej spuściźnie i tradycji zakonów mniszych, a zwłaszcza żebrzących i kleryckich, są zgromadzenia zakonne męskie i żeńskie. Początkowo ich rozwój ograniczało stanowisko Stolicy Apostolskiej zawarte w dwóch dokumentach papieża Piusa V. W bulli Circa pastoralis z 1566 roku, skierowanej do instytutów żeńskich, papież żądał, aby członkinie składały uroczyste śluby zakonne, przestrzegały klauzury i nie przyjmowały nowych kandydatek. W konstytucji apostolskiej Lubricum vitae genus (1568) odniósł się do instytutów męskich, nakazując ich członkom, aby składali śluby uroczyste, przedstawili w ciągu 24 godzin swoje konstytucje i przed upływem miesiąca

29 Por. M. Daniluk, Encyklopedia..., dz. cyt., s. 351; S. Tylus, Stowarzyszenia życia apostolskiego, w: E. Gigilewicz (red.), Encyklopedia katolicka, t. 18, Lublin 2013, k. 989-990.

30 Por. M. DAniluk, Encyklopedia..., dz. cyt., s. 351-352; S. Tylus, Stowarzyszenia życia apostolskiego, dz. cyt., k. 990. 
przyjęli regułę zakonną wcześniej zatwierdzoną przez Stolicę Apostolską. Restrykcje nałożone na zgromadzenia żeńskie złagodził papież Benedykt XIV w konstytucji apostolskiej Quamvis iusto z 1749 roku $^{31}$. Pierwsze zgromadzenie męskie pod nazwą Księża Świeccy Nauki Chrześcijańskiej (doktrynarze) powstało w 1592 roku w Awinionie i zostało zatwierdzone w 1597 roku przez papieża Klemensa VIII bullą Exposcit debitum ${ }^{32}$.

Na przełomie XVII i XVIII wieku misyjny profil charyzmatu apostolskiego zgromadzeń zakonnych męskich i żeńskich był ukierunkowany na działalność charytatywną, wychowawczą wobec dzieci i młodzieży oraz głoszenie misji ludowych. Najbardziej znaczący wkład w to dzieło wnieśli m.in.: bracia szkolni, pasjoniści i redemptoryści ${ }^{33}$.

W latach 1800-1900, głównie we Francji, a następnie w Hiszpanii i we Włoszech, powstało około 625 zgromadzeń męskich i żeńskich zatwierdzonych przez Stolicę Apostolską na prawie papieskim. Ich dynamiczny wzrost inspirowała ówczesna sytuacja religijno-społeczna Kościoła mająca swoją przyczynę w jego wewnętrznym kryzysie, a także propagowanych ideach Wielkiej Rewolucji Francuskiej z 1789 roku. Wystarczy wspomnieć szerzącą się laicyzację, przybierające na sile nastroje antyklerykalne i antykościelne oraz kasatę wszystkich zakonów, które nie zajmowały się szkolnictwem ${ }^{34}$. Stąd też nowe zgromadzenia zakonne, bazując na duchowości benedyktyńskiej, augustiańskiej, dominikańskiej, franciszkańskiej, jezuickiej i karmelitańskiej, chrystocentrycznej szkole francuskiej kard. Bérulle’a, a także pobożności maryjnej i eucharystycznej, przyjmowały apostolat dzieci i młodzieży, ludzi starych, chorych, niepełnosprawnych, więźniów, robotników, w sektorze katechetycznym, dziennikarskim oraz prowadzenia misji ludowych i ad gentes ${ }^{35}$.

Charakter zakonny zgromadzeń na ślubach zwykłych powstałych w XIX wieku zatwierdził w 1900 roku papież Leon XIII w konstytucji

${ }^{31}$ Por. E. Ziemann, Zgromadzenia zakonne, w: E. Gigilewicz (red.), Encyklopedia katolicka, t. 20, Lublin 2014, k. 1371-1372.

${ }^{32}$ Zob. M. Daniluk, E. Ziemann, Męskie zgromadzenia zakonne i stowarzyszenia życia apostolskiego na prawie papieskim, Kraków 2012, s. 40; A. L. АмAт, La vita..., dz.cyt., s. 414.

${ }_{33}$ Por. A. L. Amat, La vita..., dz. cyt., s. 415-426.

${ }^{34}$ Por. E. Ziemann, Być kapłanem..., dz. cyt., s. 18. 24-36.

35 Por. A. L. Амat, La vita..., dz. cyt., s. 442-460. 
apostolskiej Conditae a Christo, zaś w 1901 roku w Normae została określona ich wewnętrzna struktura. Kodeks prawa kanonicznego z 1917 roku (kan. 488 §2) zaliczył zgromadzenia zakonne na ślubach zwykłych czasowych lub wieczystych do stanu zakonnego, a kodeks z 1983 (kan. 607) nadał zakonom i zgromadzeniom zakonnym wspólną nazwę - instytut zakonny $^{36}$.

Spośród wszystkich zgromadzeń męskich i żeńskich założonych w XIX wieku, które w 2. połowie XX wieku liczyły około 5 tysięcy członków, na uwagę zasługują m.in.: salezjanie, siostry Sacré Coeur, maryści, siostry szkolne Matki Boskiej, Zgromadzenie Misjonarzy Oblatów Najświętszej Maryi Panny Niepokalanej i werbiści ${ }^{37}$.

\section{Sercański charyzmat Dehona w zbawczej misji Kościoła}

W kontekst powstających w XIX wieku zgromadzeń zakonnych wpisało się Zgromadzenie Księży Najświętszego Serca Jezusowego ${ }^{38}$, które zostało założone w 1878 roku w Saint Quentin we Francji przez ks. Jana Leona Dehona ${ }^{39}$. Jako klerycki instytut zakonny posiadało od początku własną tożsamość, a także specyficzny cel, nierozłącznie związany charyzmatem Założyciela.

\section{Ojciec Jan Leon Dehon - kapłan i zakonnik}

Od 1855 roku młody Dehon kształtował swoją duchowość chrześcijańską w nurcie francuskiej szkoły duchowości kard. Bérulle’a. Początkowo w kolegium jezuitów w Hazebrouck ${ }^{40}$, gdzie w 1856 roku doświadczył charyzmatu powołania kapłańskiego. Następnie jako student

${ }^{36}$ Por. B. Szewczul, Zgromadzenie zakonne, w: M. Sitarz (red.), Leksykon prawa..., dz. cyt., k. 3150-3158.

37 Por. A. L. Amat, La vita..., dz. cyt., s. 461-499.

38 Zob. E. Ziemann, Sercanie, w: E. Gigilewicz (red.), Encyklopedia katolicka, t. 18, Lublin 2013, k. 2-4.

39 Zob. M. Daniluk, Dehon Léon, w: R. Łukaszyk (red.), Encyklopedia katolicka, t. 3, Lublin 1979, k. 1098-1099.

40 Por. E. Ziemann, Być kapłanem..., dz. cyt., s. 37-40. 
prawa na paryskiej Sorbonie był zaangażowany w apostolat ewangelizacyjny i społeczny u sulpicjanów ${ }^{41}$, a także we Francuskim Seminarium św. Klary w Rzymie ${ }^{42}$, gdzie przebiegała cała jego formacja do kapłaństwa. Wszechstronnie wykształcony w zakresie nauk teologicznych, filozoficznych, prawnych i ekonomicznych, przyjął w 1868 roku w Rzymie święcenia kapłańskie. W 1871 roku wrócił do rodzinnej diecezji Soissaint, aby w robotniczej parafii Saint Quentin rozpocząć działalność duszpasterską i apostolską. W celu owocnej realizacji charyzmatu kapłańskiego, na bazie zdobytych wcześniej doświadczeń, zorganizował m.in.: Patronat św. Józefa, Katolickie Koło Robotnicze, Koło Studiów Religijno-Społecznych, Diecezjalne Oratorium Kapłańskie, a także organizował kongresy społeczne oraz założył Diecezjalne Biuro Stowarzyszeń Robotniczych ${ }^{43}$. Wprawdzie kapłaństwo służebne stanowiło dla Dehona najwyższą wartość, ze względu na jego godność i misję w Kościele, to jednak odczuwał pewien wewnętrzny niepokój związany z przyjęciem charyzmatu życia zakonnego ${ }^{44}$. Powołanie zakonne odczytywał jako charyzmatyczną misję powierzoną człowiekowi przez Boga w Kościele i dla Kościoła.

Dehon od czasu pobytu w kolegium w Hazebruck utrzymywał liczne kontakty z przedstawicielami męskich instytutów zakonnych, jednak żaden z nich nie odpowiadał swoją duchowością jego charyzmatowi, który był ukierunkowany na realizację ideału miłości i wynagrodzenia Najświętszemu Sercu Jezusa w duchu prywatnych objawień z Paray-le-Moniale i La Salette ${ }^{45}$.

Rozeznawanie powołania zakonnego przez Dehona stanowiło przedmiot jego rozmyślań i modlitwy na wszystkich odprawianych rekolek-

41 Por. M. Chmielewski, Wielka księga..., dz. cyt., s. 549-552; E. Ziemann, Być kapłanem..., dz.cyt., s. 40-43.

42 Por. E. Ziemann, Być kapłanem..., dz. cyt., s. 43-49.

${ }^{43}$ Por. tamże, s. 55-60.

44 „Miałem powołanie zakonne od mojej młodości. Miałem zawsze taki wniosek po odprawieniu rekolekcji. Lecz brakowało mi oświeceń, aby wybrać tę czy inną wspólnotę. Poszukiwałem i czekałem. Całkowite moje upodobanie odczuwałem względem Najświętszego Serca i wynagrodzenia”. L. DeHon, Lettere circolari, Bologna, s. 320 (dalej: LCr); E. Ziemann, Być kapłanem..., dz. cyt., s. 55-61.

45 Por. L. Dehon, Notes sur l'histoire de ma vie (dalej: NHV), t. 7, Roma 1979, s. 28-30. 73. 
cjach. W czasie tzw. rekolekcji powołaniowych dokonał zestawienia racji, które przemawiały za pozostaniem kapłanem diecezjalnym i ubogaceniem swojego kapłaństwa założycielskim charyzmatem zakonnym ${ }^{46}$. Ostateczna decyzja o założeniu nowego Zgromadzenia zakonnego, bazującego na duchowości, pobożności i kulcie Najświętszego Serca Jezusowego, realizującego ideał miłości i wynagrodzenia w postawie Ecce venio - Wcielonego Słowa i Ecce ancilla - Maryi, czystej miłości, oblacji, immolacji i kulcie Eucharystii, została podjęta w Loreto - w sanktuarium Zwiastowania i Wcielenia Chrystusa ${ }^{47}$.

W dniach 16-30 lipca 1877 roku Dehon odprawił rekolekcje, napisał konstytucje i reguły dla nowego Zgromadzenia, wzorowane na konstytucjach Ignacego Loyoli, po czym rozpoczął swój nowicjat, przyjmując imię Jan od Serca Jezusa. Dnia 28 czerwca 1878 roku, w uroczystość Najświętszego Serca Jezusowego, złożył śluby zakonne i dał początek kleryckiemu Zgromadzeniu Oblatów Najświętszego Serca Jezusowego. Jego charyzmat i cel, jako zgromadzenia mieszanego opartego na czynnym apostolacie oraz kontemplacji, określały dwie zasady. Pierwsza odnosiła się do czynnego zaangażowania się w ewangelizacyjną misję Kościoła. Druga zaś wiązała się z potrzebą wewnętrznego nastawienia do działalności apostolskiej, by żyć duchowością wynagradzającą inspirowaną przez kontemplację Ecce venio Jezusa Chrystusa Najwyższego i Wiecznego Kapłana ${ }^{48}$.

Rozwijające się Zgromadzenie napotykało obiektywne trudności zarówno o charakterze czysto wewnętrznym, jak i zewnętrznym, wynikającym z uwarunkowań polityczno-społecznych Kościoła francuskiego. W wyniku zaistniałej sytuacji Święte Oficjum rozwiązało oblatów 3 grudnia 1883 roku, a następnie reaktywowało 29 marca 1884 roku, jednak już pod nową nazwą - Zgromadzenie Księży Najświętszego Serca Jezusowego. Na uwagę zasługuje fakt, iż mimo zmiany nazwy Zgromadzenia pozostały niezmienne jego cel i misja - powołanie kapłańskie sercanina jest związane z nabożeństwem do Najświętszego Serca Jezusa, gorliwym szerzeniem Jego królestwa przez praktykę ducha miłości, wy-

\footnotetext{
46 Por. NHV, t. 6, Roma 1978, s. 185-187.

${ }_{47}$ Por. NHV, t. 7, s. 1-2. 34-35.

48 Por. E. Ziemann, Być kapłanem..., dz. cyt., s. 65-66.
} 
nagrodzenia, immolacji i adoracji eucharystycznej. W tym duchu mają być też podejmowane zwłaszcza te obowiązki, które wymagają ofiary i wyrzeczenia: troska o biednych, praca wśród robotników oraz misje ad gentes określone w konstytucjach. W czasie audiencji Dehona u Leona XIII papież wypowiedział się pozytywnie o Zgromadzeniu i akcentował wagę jego misji w Kościele. Ponadto zachęcał Dehona do czujności nad wiernością realizacji zwłaszcza tych elementów charyzmatu, które świadczą o jego specyfice i oryginalności w Kościele, a także akcentował konieczność wynagrodzenia, modlitwy, dążenia do świętości kapłańskiej, adoracji wynagradzającej, propagowania społecznych encyklik papieskich oraz troski o rozwój apostolatu misyjnego ad gentes. W wyniku tej audiencji uległ zmianie misyjny wymiar Zgromadzenia. Opierając się na wskazaniach Leona XIII, Dehon położył nacisk na profesjonalne prowadzenie apostolatu społecznego m.in. przez propagowanie w prasie katolickiej społecznej nauki Kościoła, czynne uczestnictwo członków Zgromadzenia w kongresach robotniczych, formację duchową, kulturalną, pastoralną i społeczną duchowieństwa oraz podejmowanie nowych wyzwań związanych z misją kapłaństwa służebnego. Mając zaś na uwadze misję ewangelizacyjną Europy, akcentował pilną potrzebę ofiarnego podejmowania apostolatu na odległych kontynentach przez zaangażowanie Zgromadzenia w misje ad gentes ${ }^{49}$.

Chociaż misje te nie stanowiły celu specyficznego Zgromadzenia, to jednak Dehon zabiegał u bpa Thibaudiera o zgodę na podjęcie tej formy apostolatu. I tak, pierwsza misja powstała w 1888 roku w Ekwadorze, a po jej zamknięciu w 1896 roku utworzono misje w 1897 w Kongu Belgijskim (obecnie Demokratyczna Republika Konga), w 1903 w południowej Brazylii, w 1907 w Finlandii, w 1909 w Austrii, w 1910 w Kanadzie i Ameryce Południowej, w 1912 w Kamerunie, w 1923 w Afryce Południowej, Ameryce Północnej oraz Indonezji ${ }^{50}$.

49 Por. LCr, s. 159. 297-299. 312-315. 365. 389; L. Dehon, Notes quotidiennes, t. 1 , Andria 1988, s. 229-230; NHV t. 8, Rzym 1983, s. 134; E. Ziemann, Być kapłanem..., dz. cyt., s. 67-71.

50 Por. Historia Congregationis SCJ 1878-1978, Roma 1978, t. 1, s. 3-8; G. Manzoni, Leone Dehone e il suo messaggio, Roma 1989, s. 329-345. 
Po audiencji u Piusa X, w dniu 21 lutego 1912 roku, Dehon sformułował postanowienia oparte na radach papieża i konstytucjach Zgromadzenia. Według Założyciela sercanów Zgromadzenie ma potrójny cel. To: 1. żarliwa gorliwość apostolska - umiłowanie pracy dla dusz w nauczaniu, przepowiadaniu i na misjach, zgodnie z potrzebami Zgromadzenia; konstytucje wskazują preferowane pola pracy: nauczanie dzieci i młodzieży, głoszenie rekolekcji, służba najbardziej marginalizowanym, robotnikom, biednym i pracy na misjach dalekich, wymagających poświęcenia i ofiary; 2. adoracja wynagradzająca - jest ona codzienną audiencją królewską sercanina oraz jego powołaniem; w każdym domu Zgromadzenia winny być wyznaczone dni wystawienia Najświętszego Sakramentu, a każdy zakonnik jest zobowiązany do codziennej półgodzinnej adoracji; 3. codzienna oblacja samych siebie Najświętszemu Sercu Jezusa - oblację określają konstytucje oraz akt oblacji dołączony do ślubów; codzienna oblacja obejmuje wszystkie prace, cierpienia, ducha ofiary i immolacji w duchu wynagrodzenia Sercu Jezusowemu; poranny akt oblacji należy odnawiać mentalnie kilka razy w ciągu dnia ${ }^{51}$.

Ojciec Leon Dehon, dostrzegając apostolskie potrzeby Kościoła, nie tracił z oczu zasadniczego celu swojego Zgromadzenia, a mianowicie: życia oblacją wynagradzającą w łączności z Chrystusem, całopalną Ofiarą miłości złożoną Ojcu za zbawienie rodzaju ludzkiego. Zgromadzenie bowiem, jako dar Ducha Świętego dla Kościoła, otrzymało charyzmat miłości ofiarnej na wzór miłości Syna do Ojca, praktykowanej przez poświęcenie, czystą miłość, całkowite poddanie się woli Bożej, dar z samego siebie, świętość kapłańską, adorację eucharystyczną oraz wynagrodzenie ${ }^{52}$.

Istotne miejsce w prezentacji misji i charyzmatu Zgromadzenia stanowią Konstytucje zakonne oraz Dyrektorium duchowe (Directoire spirituel des Prêtres du Sacré-Coeur de Jésus) Założyciela z 1919 roku. Dyrektorium, jako zbiór zasad życia duchowego, prezentuje duchowość ojca Dehona przekazaną swoim zakonnikom. Zawarte w nim treści wyznaczają fundamentalne linie duchowości sercańskiej w kontekście

51 Por. LCr, s. 365-367.

52 Por. A. Vassena, Il primato delloblazione di amore nel carisma di padre Dehon, „Dehoniana” 44 (1979), s. 143-156; L. Dehon, Oeuvres spirituelles, t. 7, Andria 1985, s. 13-24. 
charyzmatycznej istoty powołania i misji kapłana sercanina w Kościele. Dyrektorium w pierwszej wersji stanowiło integralną część Konstytucji z 1881 roku, zaś w odnowionych Konstytucjach z 1885 roku jego treść została umieszczona w VIII i IX rozdziale ${ }^{53}$.

\section{Misyjność charyzmatu sercańskiego w nowych Konstytucjach (Regule życia)}

II Sobór Watykański w Dekrecie o przystosowanej do współczesności odnowie życia zakonnego Perfectae caritatis (1965), a następnie Paweł VI w motu proprio Ecclesiae Sanctae (1966), dali przepisy wykonawcze do niektórych dekretów soborowych, zwrócili uwagę na konieczność przeprowadzenia rewizji konstytucji instytutu, zwłaszcza pod kątem pogłębionej refleksji nad charyzmatem założyciela oraz sposobu przeżywania charyzmatu i wcielania go w życie instytutu. Obecne Konstytucje sercanów, będące owocem wieloletniej pracy na bazie dialogu międzyprowincjalnego, w prowincjach oraz odbytych kapituł generalnych, zostały wydane w 1986 roku. Najnowsze, typiczne wydanie Konstytucji zatwierdzonych w 2009 roku przez Kongregację Instytutów Życia Konsekrowanego i Stowarzyszeń Życia Apostolskiego było podyktowane wprowadzeniem nowej terminologii struktur Zgromadzenia oraz urzędów, a także pracą nad Dyrektorium generalnym, które wraz Konstytucjami tworzy Regułe życia ${ }^{54}$.

Zagadnienie misji i charyzmatu Zgromadzenia w nowych Konstytucjach jest zawarte już w prologu wskazującym na ich początek, cel i naturę $e^{55}$. Przyjęcie tego charyzmatu przez Dehona było związane z jego głębokim doświadczeniem wiary w zbawczą miłość Zbawiciela (por. Ga 2,22),

53 Por. G. Manzoni, Leone Dehon..., dz. cyt., s. 474-478.

54 Por. Reguła życia Zgromadzenia Księży Najświętszego Serca Jezusowego (Księża Sercanie). Konstytucje i Dyrektorium generalne, Rzym 2009 (dalej: Konst.), s. 9-12.

55 „Zgromadzenie Księży Najświętszego Serca Jezusowego zostało założone przez ojca Leona Jana Dehona, który otrzymał łaskę i misję wzbogacenia Kościoła zakonnym instytutem apostolskim, żyjącym jego natchnieniem ewangelicznym. Zostało powołane, by wydać owoce tego charyzmatu zgodnie z wymogami Kościoła i świata”. Konst., 1. 
sugestywnie wyrażoną w otwartym Boku i przebitym Sercu Jezusa. Ojciec Dehon, pociągnięty tą miłością, tak często odrzucaną przez ludzki grzech zarówno na płaszczyźnie osobistej, jak i społecznej, odczuwał głębokie pragnienie zjednoczenia się z Sercem Jezusa w celu budowania Jego królestwa w duszach i społecznościach. Skutki tego zjednoczenia będą widoczne w całym życiu Założyciela, a zwłaszcza w apostolstwie ukierunkowanym na ludzi szczególnie bezbronnych oraz w zaradzaniu duszpasterskim brakom Kościoła. W tym kontekście Dehon oczekuje, aby jego zakonnicy byli prorokami miłości, a także sługami pojednania „ludzi i świata w Chrystusie”. Zgromadzenie bowiem powstało dla służby Kościołowi, zachowując własny, specyficzny i pierwotny charakter, który łączy życie zakonne i apostolskie z oblacją wynagradzającą Chrystusa złożoną Ojcu za ludzi ${ }^{56}$.

Sercanie, żyjąc w Zgromadzeniu dziedzictwem ojca Dehona, są zakonnikami poświęconymi Chrystusowi przez profesję rad ewangelicznych zgodnie z przyjętą przez Kościół duchowością ich Założyciela. Jest rzeczą znamienną, iż poświęcenie samo w sobie jest owocne apostolsko w służbie misji. Podobnie też każdy charyzmat w Kościele, w tym również proroczy charyzmat sercański oddaje członków Zgromadzenia na służbę w zbawczej misji ludu Bożego ${ }^{57}$.

Jak podkreślają Konstytucje, zgromadzenie sercanów jest ze swej natury zakonnym instytutem apostolskim. Z tego względu oddaje się na służbę Kościoła w różnorodności jego wyzwań duszpasterskich. I chociaż nie zostało założone dla konkretnego dzieła apostolskiego, to jednak otrzymało specyficzne ukierunkowanie apostolskie charakteryzujące jego misję w Kościele ${ }^{58}$. Specyficznym rysem tej misji w duchu miłości i oblacji jest adoracja eucharystyczna, będąca służbą Kościołowi. Ważne miejsce w tym kontekście zajmuje też posługiwanie ludziom biednym, pogardzanym i robotnikom. Biorąc jednak pod uwagę preferencje w służbie apostolskiej, uprzywilejowane miejsce zajmuje działalność misyjna. Jak akcentują Konstytucje, całe Zgromadzenie jest obecne w posłudze ewan-

\footnotetext{
56 Por. Konst., 2. 4-7.

57 Por. Konst., 26-27.

${ }_{58}$ Por. Konst., 30.
} 
gelizacyjnej misjonarzy. W celu owocnego prowadzenia tej formy apostolatu kapłani i zakonnicy Najświętszego Serca Jezusa winni troszczyć się o solidną formację opartą na duchowości sercańskiej ${ }^{59}$.

Zgromadzenie Księży Sercanów, jako klerycki instytut zakonny, o charakterze międzynarodowym, jest powołane do uniwersalnej służby w misji Kościoła, uwzględniającej jego uwarunkowania kulturowe, społeczne i eklezjalne. Stąd też indywidualne lub wspólnotowe zaangażowanie $\mathrm{w}$ to dzieło sprzyja rozszerzaniu się Zgromadzenia na tereny jeszcze nieobjęte misją ewangelizacyjną bądź też przeżywające problemy personalne i ekonomiczne. Realizując charyzmat misji apostolskiej ojca Dehona, członkowie Prowincji Polskiej sercanów podejmowali w przeszłości i nadal podejmują wielorakie zaangażowania o charakterze misyjnym w Zgromadzeniu. Aktualnie są obecni w Albanii, Austrii, Belgii, na Białorusi, w Chile, Chinach, Chorwacji, Czadzie, na Filipinach, w Finlandii, Francji, Indonezji, Irlandii, Kongu, Mołdawii, Niemczech, Południowej Afryce, na Słowacji, w Szwajcarii, Stanach Zjednoczonych Ameryki i na Ukrainie.

\section{Zakończenie}

Misyjny wymiar charyzmatu sercańskiego odzwierciedlają wielorakie formy apostolatu podejmowanego przez członków Zgromadzenia w kontekście potrzeb misji ewangelizacyjnej Kościoła. Każda bowiem jednostka Zgromadzenia, opierając swoją działalność na charyzmacie Założyciela zawartym w Konstytucjach oraz na własnym doświadczeniu apostolskim, podejmuje specyficzne zaangażowania. Warto podkreślić, iż elementem dynamizującym misyjny wymiar charyzmatu sercańskiego jest duchowość, będąca nierozerwalnie związana z charyzmatem oraz sposobem jego przeżywania. Istotą misyjnego charyzmatu Zgromadzenia jest miłość i wynagrodzenie względem Najświętszego Serca Jezusowego w duchu oblacji i immolacji. Stąd też forma działalności apostolskiej Zgromadzenia jest przede wszystkim misyjna, zarówno w wymiarze globalnym, jak i lokalnym Kościoła.

\footnotetext{
59 Por. Konst., 31-33.
} 


\section{Bibliografia}

Amat A. L., La vita consacrata le varie forme dalle origini ad oggi, Roma 1991.

Boureau R., Loratoire en France, Paris 1991.

Chmielewski M., Wielka księga duchowości katolickiej, Kraków 2015.

Daniluk M., Dehon Léon, w: R. Łukaszyk (red.), Encyklopedia katolicka, t. 3, Lublin 1979, k. 1098-1099.

Daniluk M., Encyklopedia instytutów życia konsekrowanego i stowarzyszeń życia apostolskiego, Lublin 2000.

Daniluk M., Mnisze zakony, w: E. Ziemann (red.), Encyklopedia katolicka, t. 12, Lublin 2008, k. 1458.

Daniluk M., Reguła Mistrza, w: E. Gigilewicz (red.), Encyklopedia katolicka, t. 16, Lublin 2012, k. 1328-1329.

Daniluk M., Ziemann E., Męskie zgromadzenia zakonne i stowarzyszenia życia apostolskiego na prawie papieskim, Kraków 2012.

Dehon L., Lettere circolari, Bologna 1954.

Dehon L., Notes quotidiennes, t. 1, Andria 1988.

Dehon L., Notes sur l'histoire de ma vie, t. 6, Roma 1978.

Dehon L., Notes sur l'histoire de ma vie, t. 7, Roma 1979.

Dehon L., Notes sur l'histoire de ma vie, t. 8, Roma 1983.

Dehon L., Oeuvres spirituelles, t. 7, Andria 1985.

Gajda J., Misyjna duchowość, w: M. Chmielewski (red.), Leksykon duchowości katolickiej, Lublin-Kraków 2002, s. 542-545.

Gogola J., Zasady wierności charyzmatowi założyciela, Kraków 2000.

Historia Congregationis SCJ 1878-1978, Roma 1978.

Jan Paweł II, Posynodalna adhortacja apostolska Vita consecrata, Rzym 1996.

Jasiak R., Charyzmaty, w: M. Chmielewski (red.), Leksykon duchowości katolickiej, Lublin-Kraków 2002, s. 112-113.

Kasprzak S., Misje, w: M. Sitarz (red.), Leksykon prawa kanonicznego, Lublin 2019, k. 1751-1756. 
Kłoczowski J., Wspólnoty chrześcijańskie, Kraków 1964.

Manzoni G., Leone Dehone e il suo messaggio, Roma 1989.

Marecki J., Zakony w Polsce, Kraków 2000.

Paweł VI, Adhortacja Evangelica testificatio, Rzym 1971.

Reguła życia Zgromadzenia Księży Najświętszego Serca Jezusowego (Księża Sercanie). Konstytucje i Dyrektorium generalne, Rzym 2009.

II Sobór Watykański, Dekret o apostolacie świeckich Apostolicam actuositatem, Rzym 1965.

II Sobór Watykański, Dekret o działalności misyjnej Kościoła Ad gentes divinitus, Rzym 1965.

II Sobór Watykański, Dekret o posłudze i życiu kapłanów Presbyterorum ordinis, Rzym 1965.

II Sobór Watykański, Dekret o przystosowanej do współczesności odnowie życia zakonnego Perfectae caritatis, Rzym 1965.

II Sobór Watykański, Konstytucja dogmatyczna o Kościele Lumen gentium, Rzym 1964.

II Sobór Watykański, Konstytucja dogmatyczna o Objawieniu Bożym Dei Verbum, Rzym 1965.

Szewczul B., Zgromadzenie zakonne, w: M. Sitarz (red.), Leksykon prawa kanonicznego, Lublin 2019, k. 3150-3158.

Tylus S., Stowarzyszenia życia apostolskiego, w: E. Gigilewicz (red.), Encyklopedia katolicka, t. 18, Lublin 2013, k. 989-990.

Vassena A., Il primato delloblazione di amore nel carisma di padre Dehon, „Dehoniana" 44 (1979), s. 143-156.

Wytrwał T., Zakony Trzecie, w: E. Gigilewicz (red.), Encyklopedia katolicka, t. 20, Lublin 2014, k. 1196-1197.

Ziemann E., Być kapłanem Serca Jezusowego, Kraków 2006.

Ziemann E., Oratorianie francuscy, w: E. Gigilewicz (red.), Encyklopedia katolicka, t. 14, Lublin 2010, k. 709-710.

Ziemann E., Sercanie, w: E. Gigilewicz (red.), Encyklopedia katolicka, t. 18, Lublin 2013, k. 2-4. 
Ziemann E., Zakon, w: E. Gigilewicz (red.), Encyklopedia katolicka, t. 20, Lublin 2014, k. 1191-1192.

Ziemann E., Zgromadzenia zakonne, w: E. Gigilewicz (red.), Encyklopedia katolicka, t. 20, Lublin 2014, k. 1371-1372.

Ks. Eugeniusz Ziemann SCJ - sercanin, doktor teologii, wykładowca teologii duchowości sercańskiej w Wyższym Seminarium Misyjnym Księży Sercanów w Stadnikach; członek Polskiego Stowarzyszenia Teologów Duchowości i Polskiego Towarzystwa Teologicznego. 